\title{
Gambaran Kadar Ureum Dan Kreatinin Penderita Penyakit Ginjal Kronik (Pgk) Yang Terinfeksi Malaria Di Rumah Sakit Umum Daerah Jayapura
}

\author{
Sabakthani Kayoi ${ }^{1}$, Ni Putu Rahayu ${ }^{2}$, I Wayan Tanjung Aryasa ${ }^{3}$ \\ ${ }^{1,2,3}$ Program Studi Teknologi Laboratorium Medik, Universitas Bali Internasional \\ Email : sanikayoi22@gmail.com
}

\begin{abstract}
Tanggal Submit:

26 Agustus 2020

Tanggal Review:

5 November 2020

Tanggal Publish

Online:

20 Desember 2020

The aim of the study was to see the comparison of urea and creatinine levels in chronic kidney disease patients between those infected with malaria and those not infected with malaria at the Jayapura Regional General Hospital. This type of research is retrospective analytic. The samples of this study were chronic kidney patients who were infected with malaria and conducted an examination at the Jayapura Regional General Hospital that met the inclusion criteria, in order to obtain 30 positive malaria samples. The average urea level of female CKD patients infected with malaria was $116.7 \mathrm{mg} / \mathrm{dL}$, the lowest was $63,8 \mathrm{mg} / \mathrm{dL}$ and the highest was $136,2 \mathrm{mg} / \mathrm{dL}$. The average urea level of male CKD patients infected with malaria was $95,9 \mathrm{mg} / \mathrm{dL}$, the lowest was $33.4 \mathrm{mg} / \mathrm{dL}$ and the highest was $231,0 \mathrm{mg} / \mathrm{dL}$. The result of the mean creatinine level of female CKD patients infected with malaria was $17,5 \mathrm{mg} / \mathrm{dL}$, the lowest was $9,92 \mathrm{mg} / \mathrm{dL}$ and the highest was $31,38 \mathrm{mg} / \mathrm{dL}$. While the mean creatinine level of male CKD patients infected with malaria was $12,0 \mathrm{mg} / \mathrm{dL}$, the lowest was $3,49 \mathrm{mg} / \mathrm{dL}$ and the highest was $26,27 \mathrm{mg} / \mathrm{dL}$.
\end{abstract}

Keywords: chronic kidney disease, malaria, urea and creatinine.

\section{PENDAHULUAN}

Perkembangan penyakit semakin berkembang setiap tahunnya, baik dari perkembangan jenis penyakitnya maupun jumlah penderitanya.Penyakit dalam adalah suatu penggolongan penyakit di dalam dunia kedokteran yang mempunyai ragam penyakit yang paling banyak dan sampai saat ini penggolongannya masih terus berlangsung.Salah satu yang termasuk penyakit dalam adalah gagal ginjal kronik (Sitti, 2018).

Penyakit Ginjal Kronik (PGK) adalah suatu gangguan pada ginjal ditandai dengan abnormalitas struktur ataupun fungsi ginjal yang berlangsung lebih dari 3 bulan. PGK ditandai dengan 
satu atau lebih tanda kerusakan ginjal yaitu albuminuria, abnormalitas sedimen urin, elektrolit, histologi, struktur ginjal, ataupun adanya riwayat transplantasi ginjal, juga disertai penurunan laju filtrasi glomerulus (Sitifa et al., 2018). Kadar ureum dan kreatinin serum ini perlu dimonitor sebagai indikator kerusakan ginjal dan pemeriksaan ini dilakukan setiap akan menjalani terapi hemodialisis, seringkali terlihat bahwa kadar ureum dan kreatinin serum pasien yang akan menjalani terapi hemodialisis kadarnya berubah-ubah, bahkan melebihi kadar normal (Suryawan et al., 2016).

\section{World Health Organization} (WHO) memaparkan bahwa dari tahun 2009 sampai tahun 2011 sebanyak 36 juta orang warga dunia meninggal dunia akibat penyakit ginjal kronis. Penyakit ginjal kronis di Indonesia diperburuk karena adanya proses infeksi yang sering terjadi sehubungan dengan penyakit-penyakit yang ada pada daerah dengan iklim tropis, salah satunya penyakit malaria. Penyebab lainnya adalah adanya gangguan metabolik seperti diabetes melitus, hipertensi, glomerulonefritis dan penyakit lainnya yang berhubungan dengan obstruksi (Astuti, 2017 ).
Malaria merupakan salah satu penyakit menular yang mempengaruhi angka kematian bayi, anak dan ibu melahirkan serta dapat menurunkan produktivitas kerja. Angka kesakitan penyakit ini masih cukup tinggi terutama di kawasan timur Indonesia. Kejadian luar biasa (KLB) malaria masih sering terjadi terutama didaerah yang terjadi perubahan lingkungan, misalnya tambak udang atau ikan yang tak terpelihara, penebangan pohon bakau sebagai bahan bakar dan arang, muara sungai yang tersumbat yang akan menjadi tempat perindukan nyamuk malaria (Akhsin, 2011). Menurut Dinas Kesehatan Provinsi Papua tahun 2016, di Papua terdapat 424.083 penderita yang diduga malaria dan 155.670 kasus yang terbukti positif malaria berdasarkan hasil pemeriksaan apusan darah (Josephine, 2018).

Malaria adalah penyakit infeksi yang disebabkan oleh parasit Plasmodium yang dapat ditandai dengan demam, hepatosplenomegali dan anemia. Plasmodium hidup dan berkembang biak dalam sel darah merah manusia. Penyakit ini secara alami ditularkan melalui gigitan nyamuk Anopheles betina (Kemenkes, 2013). Pada infeksi malaria berat dapat terjadi gangguan fungsi ginjal. Gangguan ginjal 
diduga disebabkan adanya anoksia karena penurunan aliran darah ke ginjal akibat dari sumbatan kapiler sehingga terjadi penurunan filtrasi glomerulus. Parasit di dalam eritrosit akan ke kapiler organ ginjal dan mampu bersekuestrasi, sithoadherensi, dan membentuk rosset yang dapat menyumbat kapiler-kapiler dan akhirnya ginjal kekurangan suplai oksigen (Isa, 2012). Berdasarkan hal tersebut peneliti ingin melakukan penelitian dengan judul “ Gambaran Kadar Ureum dan Kreatinin Penderita Penyakit Ginjal Kronik yang Terinfeksi Malaria di Rumah Sakit Umum Daerah Jayapura “.

\section{METODE}

Penelitian mengenai hubungan peningkatan kadar ureum dan kreatinin pada pasien penyakit ginjal kronik yang terinfeksi malaria ini merupakan jenis penelitian analitik retrospektif dari tahun 2018-2019 dengan desain crosssectional study. Penelitian retrospektif yaitu rancangan bangun dengan melihat kebelakang dari suatu kejadian yang berhubungan dengan kejadian kesakitan yang diteliti (Nasir et al., 2018). Penelitian ini bersifat retrospektif karena data yang digunakan dalam penelitian ini diambil dengan melakukan penelusuran data terdahulu, yaitu data hasil di laboratorium klinik. Penelitian Cross sectional adalah penelitian yang dilakukan pada satu saat atau satu periode tertentu dan pengamatan obyek studi hanya dilakukan sekali. Tempat penelitian ini dilakukan di Laboratorium Rumah Sakit Umum Daerah Jayapura. Waktu penelitian ini dari bulan Juni 2020 - Juli 2020. Populasi penelitian ini yaitu penderita penyakit ginjal kronik yang melakukan pemeriksaan malaria, ureum dan kreatinin pada Laboratorium Rumah Sakit Umum Daerah Jayapura sebanyak 30 sampel positif malaria. Analisis Data pada penelitian ini kemudian di validkan dengan statistika deskriptif.

\section{HASIL}

Karakteristik Pasien PGK Terinfeksi Malaria di Rumah Sakit Umum Daerah Jayapura

Karakteristik responden Pasien PGK terinfeksi malaria di Rumah Sakit Umum Daerah Jayapura di sajikan pada Tabel 1. 
Tabel 1. Karakteristik responden pasien PGK di RSUD Jayapura

\begin{tabular}{crr}
\hline \multicolumn{2}{c}{ Karakteristik responden } & Terinfeksi Malaria \\
\hline \multirow{2}{*}{ Usia } & 20-40 tahun & 8 orang \\
\cline { 2 - 3 } & 40-50 tahun & 7 orang \\
\cline { 2 - 3 } Jenis & 50-60 tahun & 15 orang \\
\cline { 2 - 3 } kelamin & Perempuan & 6 orang \\
\cline { 2 - 3 } & Laki-laki & 24 orang
\end{tabular}

Berdasarkan tabel diatas, pada pasien PGK yang terinfeksi malaria sebanyak 30 orang, 8 orang berusia 20 40 tahun, 7 orang berusia 40-50 tahun dan 15 orang berusia 50-60 tahun.

Hasil pemeriksaan kadar ureum pasien PGK terinfeksi malaria di

\section{Rumah Sakit Umum Dearah} Jayapura

Hasil pemeriksaan kadar ureum pasien PGK yang terinfeksi malaria di Rumah Sakit Umum Daerah Jayapura disajikan pada Tabel 2.

Tabel 2. Kadar ureum pasien PGK terinfek malaria di RSUD Jayapura

\begin{tabular}{|c|c|c|c|c|}
\hline \multirow[t]{2}{*}{$\begin{array}{l}\text { Jenis } \\
\text { kelamin }\end{array}$} & \multirow{2}{*}{$\begin{array}{l}\text { Nilai } \\
\text { rujukan }\end{array}$} & \multicolumn{3}{|c|}{$\begin{array}{c}\text { Kadar ureum pasien PGK terinfek malaria } \\
(\mathrm{mg} / \mathrm{dL})\end{array}$} \\
\hline & & Terendah & Tertinggi & Rata-rata \\
\hline Perempuan & $7-18 \mathrm{mg} / \mathrm{dL}$ & 63,8 & 136,2 & 116,7 \\
\hline Laki-laki & $7-18 \mathrm{mg} / \mathrm{dL}$ & 33,4 & 231,0 & 95,9 \\
\hline
\end{tabular}

Berdasarkan tabel diatas, rata-rata kadar ureum pasien PGK berjenis kelamin perempuan yang terinfeksi malaria di Rumah Sakit Umum Daerah Jayapura adalah 116,7 mg/dL, dengan kadar ureum terendah adalah 63,8 $\mathrm{mg} / \mathrm{dL}$ dan kadar ureum tertinggi adalah $136,2 \mathrm{mg} / \mathrm{dL}$. Sedangkan rata-rata kadar ureum pasien PGK laki-laki yang terinfeksi malaria di Rumah Sakit Umum Daerah Jayapura adalah 95,9
mg/dL, dengan kadar ureum terendah adalah 33,4 mg/dL dan kadar ureum tertinggi adalah 231,0 mg/dL.

Hasil pemeriksaan kadar kreatinin pasien PGK terinfeksi malaria di Rumah Sakit Umum Daerah Jayapura

Hasil pemeriksaan kadar kreatinin pasien PGK yang terinfeksi malaria di Rumah Sakit Umum Daerah Jayapura disajikan pada Tabel 3 . 


\section{The Joumal Of Muhammadiyah Medical Laboratory Technologist \\ Vol.3 No.2, November2020 \\ pISSN:2597-3681 e-ISSN:26142805}

Tabel 3. Kadar kreatinin pasien PGK terinfeksi malaria di RSUD Jayapura

\begin{tabular}{|c|c|c|c|c|}
\hline \multirow[t]{2}{*}{$\begin{array}{c}\text { Jenis } \\
\text { kelamin }\end{array}$} & \multirow[t]{2}{*}{ Nilai rujukan } & \multicolumn{3}{|c|}{$\begin{array}{c}\text { Kadar kreatinin pasien PGK terinfeksi malaria } \\
(\mathrm{mg} / \mathrm{dL})\end{array}$} \\
\hline & & Terendah & Tertinggi & Rata-rata \\
\hline Perempuan & $\leq 0,95 \mathrm{mg} / \mathrm{dL}$ & 9,92 & 31,38 & 17,5 \\
\hline Laki-laki & $\leq 0,96 \mathrm{mg} / \mathrm{dL}$ & 3,49 & 26,27 & 12,0 \\
\hline
\end{tabular}

Berdasarkan tabel diatas, rata-rata kadar kreatinin pasien PGK berjenis kelamin perempuan yang terinfeksi malaria di Rumah Sakit Umum Daerah Jayapura adalah 17,5 mg/dL, dengan kadar kreatinin terendah adalah 9,92 $\mathrm{mg} / \mathrm{dL}$ dan kadar kreatinin tertinggi adalah $31,38 \mathrm{mg} / \mathrm{dL}$. Sedangkan ratarata kadar kreatinin pasien PGK lakilaki yang terinfeksi malaria di Rumah Sakit Umum Daerah Jayapura adalah 12,0 $\mathrm{mg} / \mathrm{dL}$, dengan kadar ureum terendah adalah $3,49 \mathrm{mg} / \mathrm{dL}$ dan kadar ureum tertinggi adalah $26,27 \mathrm{mg} / \mathrm{dL}$.

PEMBAHASAN

Karakteristik Pasien PGK Terinfeksi Malaria di Rumah Sakit Umum

\section{Daerah Jayapura}

Subjek dalam penelitian ini adalah pasien PGK yang melakukan pemeriksaan malaria di Rumah Sakit Umum Daerah Jayapura yang memenuhi kriteria inklusi dan eksklusi. Jumlah subjek dalam penelitian ini sebanyak 30 orang yang terinfeksi malaria. Berdasarkan Tabel 1. ditunjukkan bahwa responden laki-laki lebih banyak
Jumlah pasien PGK perempuan yang terinfeksi malaria sebanyak 6 orang dan jumlah pasien PGK laki-laki yang terinfeksi malaria sebanyak 24 orang. Hasil tersebut berkaitan dengan kejadian penyakit penyebab PGK, seperti batu ginjal, yang juga banyak terjadi pada jenis kelamin laki-laki (Sitifa et al., 2018). Penelitian ini sama seperti penelitian Darmawaty et al (2008). Pada hasil penelitian tersebut jumlah laki-laki yang menderita malaria lebih banyak dibandingkan perempuan, yaitu $84,5 \%$ dan $15,2 \%$.

Penelitian yang dilakukan terhadap 30 sampel pasien PGK positif malaria kisaran umur responden antara 20 tahun hingga 60 tahun. Penurunan fungsi ginjal merupakan proses normal setiap bertambahnya usia manusia. Bertambahnya usia menunjukkan penurunan progresif Glomerular Filtrasion Rate (GFR) dan Renal Blood Flow $(R B F)$. Penurunan terjadi sekitar 8 $\mathrm{ml} / \mathrm{menit} / 1,73 \mathrm{~m}^{2}$ setiap dekadenya sejak usia 40 tahun (Sitifa et al., 2018). 


\section{Hasil pemeriksaan kadar ureum}

\section{pasien PGK terinfeksi malaria di}

\section{Rumah Sakit Umum Dearah}

\section{Jayapura}

Hasil ureum pasien PGK yang terinfeksi malaria terendah untuk perempuan $63,8 \mathrm{mg} / \mathrm{dL}$ dan untuk lakilaki $33,4 \mathrm{mg} / \mathrm{dL}$, hasil ureum tertinggi untuk perempuan 136,2 $\mathrm{mg} / \mathrm{dL}$ dan untuk laki-laki $231,0 \mathrm{mg} / \mathrm{dL}$ dan hasil rata-rata ureum pasien PGK terinfeksi malaria perempuan $116,7 \mathrm{mg} / \mathrm{dL}$ dan laki-laki 95,9 mg/dL. Data hasil yang diperoleh dari laboratorium menunjukan pasien PGK yang terinfeksi malaria mengalami peningkatan ureum dua kali lipat dari pasien yang tidak terinfeksi malaria. Pasien PGK dengan komplikasi malaria dapat mengakibatkan peningkatan ureum dalam darah, ini disebabkan adanya anoksia karena penurunan aliran darah ke ginjal akibat dari sumbatan kapiler sehingga terjadi penurunan filtrasi glomerulus. Parasit di dalam eritrosit akan ke kapiler organ ginjal dan mampu bersekuestrasi, sithoadherensi, dan membentuk rosset yang dapat menyumbat kapiler-kapiler sehingga proses eksresi sisa metabolisme menjadi terganggu ( Efraim et al., 2019).
Hasil pemeriksaan kadar kreatinin pasien PGK terinfeksi malaria di

Rumah Sakit Umum Daerah
Jayapura

Hasil kreatinin pasien PGK yang terinfeksi malaria terendah untuk perempuan $9,92 \mathrm{mg} / \mathrm{dL}$ dan untuk lakilaki 3,49 mg/dL, hasil kreatinin tertinggi untuk perempuan $31,38 \mathrm{mg} / \mathrm{dL}$ dan untuk laki-laki $26,27 \mathrm{mg} / \mathrm{dL}$ dan hasil rata-rata kreatinin pasien PGK terinfeksi malaria perempuan 17,5 $\mathrm{mg} / \mathrm{dL}$ dan laki-laki 12,0 mg/dL. Data hasil yang diperoleh dari laboratorium menunjukan pasien PGK yang terinfeksi malaria mengalami peningkatan kreatinin dua kali lipat dari pasien yang tidak terinfeksi malaria.

Pemeriksaan kadar kreatinin dalam darah merupakan salah satu parameter yang digunakan untuk menilai fungsi ginjal, karena konsentrasi dalam plasma dan ekskresinya di urin dalam 24 jam relatif konstan. Kadar kreatinin darah yang lebih besar dari normal mengisyaratkan adanya gangguan fungsi ginjal (Asri et al., 2013). Penelitian yang dilakukan oleh Siregar (2015), menyebutkan bahwa terjadi penurunan fungsi ginjal berupa kenaikan kadar ureum hingga diatas $200 \mathrm{mg} / \mathrm{dL}$ dan kreatinin diatas $9 \mathrm{mg} / \mathrm{dL}$, karena produksi urin yang masih sedikit yaitu 
$200 \mathrm{cc} / 24$ jam dan kadar ureum

kreatinin yang terus meningkat pasien

dilakukan hemodialisis.

Mengingat bervariasinya

manifestasi klinis malaria maka anamnesis riwayat perjalanan ke daerah endemis malaria pada setiap penderita dengan demam harus dilakukan. Diagnosis malaria ditegakkan seperti diagnosis penyakit lainnya berdasarkan anamnesis, pemeriksaan fisik, dan pemeriksaan laboratorium. Diagnosis pasti malaria apabila ditemukan parasit malaria dalam darah (Harijanto, 2006).

\section{SIMPULAN}

Berdasarkan hasil penelitian terdapat perbandingan kadar ureum dan kreatinin penderita penyakit ginjal kronik antara yang terinfeksi malaria dan tidak terinfeksi malaria. Pada pasien terinfeksi malaria terjadi peningkatan kadar ureum sebesar $8 \%$ dan kadar kreatinin sebesar 1,4\%.

\section{SARAN}

Saran yang dapat disampaikan adalah perlu dilakukan penelitian lebih lanjut pada jenis parasit malaria dan tingkat keparahan yang ditimbulkan pada pasien penyakit ginjal kronik.

\section{DAFTAR PUSTAKA}

Akhsin, Z. 2011. Parasitologi. Yogyakarta: Nuha Medika.

Asri. S, Puspita. D, Rosyadi. I. 2013 Perbedaan Kadar Ureum \& Creatinin Pada Klien Yang Menjalani Hemodialisa Dengan Hollow Fiber Baru Dan Hollow Fiber Re Use Di Rsud Ungaran Jurnal Keperawatan Medikal Bedah . Volume 1 (1): 15-24.

Astuti, Anggorowati, Kusuma. 2017. Self Management Terhadap Psychosocial Adjustment Pasien Penyakit Ginjal Kronis Dengan Hemodialisa. Jurnal Keperawatan Soedirman (The Soedirman Journal of Nursing), 12 (3): 181-189.

Darmawaty. Fitriani, M. Pakasi. R, Hardjoeno. 2008. Gambaran Fungsi Hati Dan Ginjal Pada Penderita Malaria. Indonesian Journal of Clinical Pathology and Medical Laboratory, Vol. 15 (1): 1-4.

Efraim. S, Melati. S, Eddy. 2019. Efek Jus Pisang Tongka Langit (Musa troglodytarum) Terhadap Ginjal Mencit (Mus musculus) Model Malaria. Jurnal Ilmu-ilmu MIPA. 19 (2): 154-168. 
Harijanto PN. Malaria. Dalam: Sudoyo AW, Setiyohadi B, Alwi I, Simadibrata M, Setiati S, ed. Buku Ajar Ilmu Penyakit Dalam. Jilid II Edisi V. Jakarta: Pusat Penerbitan Ilmu Penyakit Dalam Fakultas Kedokteran.

Isa, Rinidar, Sugito. 2012. Aktivitas Antiplasmodium Daun Sernai (Wedelia Biflora) Berdasarkan Evaluasi Fungsi Ginjal dan Hati pada Mencit yang Diinfeksi dengan Plasmodium berghei. Jurnal Veteriner, 13 (2): 167-175.

Josephine D, H. T. Rinonce, M, F, Pudjohartono, P. Astari, M. G. Winata, dan F. Kasim. 2018. Prevalensi malaria di Asmat, Papua: Gambaran situasi terkini di daerah endemik tinggi. Journal of Community Empowerment for Health, 1 (1): 11-19.

Nasir, A, B, D. A, Muhith. M, E, Ideputri. 2018. Metodologi Penelitian Kesehatan. Yogyakarta: Nuha Medika.

Nursalam. 2013. Metodologi Penelitian Kesehatan. Jakarta: PT Rineka Cipta.

Peraturan Menteri Kesehatan Republik Indonesia. 2013. PERMENKES Nomor 5 tahun 2013 Tentang Pedoman Tata Laksana Malaria.
Sitifa, A, S. Azmi, M. Yanni. 2018. Gambaran Klinis Penderita Penyakit Ginjal Kronik yang Menjalani Hemodialisis di RSUP Dr. M. Djamil Padang. Jurnal Kesehatan Andalas. 7 (1): 42-50.

Sitti, H. 2018. Analisis Perbandingan Hasil Pemeriksaan Kreatinin Darah Dengan Deproteinisasi Dan Nondeproteinisasi Metode Jaffe Reaction. Jurnal Media Analis Kesehatan. 1 (1): 26-31.

Suryawan, D, G, A. I. A. M. S. Arjani, I. G. Sudarmanto. 2016. Gambaran Kadar Ureum Dan Kreatinin Serum Pada Pasien Gagal Ginjal Kronis Yang Menjalani Terapi Hemodialisis di RSUD Sanjiwani Gianyar. jurnal 4 (2): 145-153. 